Annals of Warsaw University of Life Sciences - SGGW

Land Reclamation No 41, 2009: 11-17

(Ann. Warsaw Univ. of Life Sci. - SGGW, Land Reclam. 41, 2009)

\title{
Soil concentration of selected polycyclic aromatic hydrocarbons around the Petrochemical Plant in Plock in 1987-2006
}

\author{
LEONARD INDEKA, ZBIGNIEW KARACZUN, GRAŻYNA OBIDOSKA
}

Department of Environmental Protection, Warsaw University of Life Sciences, ul. Nowoursynowska 166, 02-787 Warsaw

\begin{abstract}
Soil concentration of selected polycyclic aromatic hydrocarbons around the Petrochemical Plant in Plock in 1987-2006. The Petrochemical Plant Orlen S.A. in Płock was constructed in the 1960s as one of the largest objects of this type in Europe. The facility was unfortunately located among agricultural areas. In the 1990s the plant implemented a number of investments aimed at lowering pollutant loads released to the environment. There is no information, however, whether these investments were successful in decreasing soil pollution with tar substances and polycyclic aromatic hydrocarbons (PAH) and raising the security level for agricultural production within the area. The aim of the research was, therefore, to provide this information. The research was conducted within the agricultural area around the plant. Soil samples were collected in the north-eastern direction from the facility, at five research points at: $1 \mathrm{~km}, 3 \mathrm{~km}, 6 \mathrm{~km}, 12$ $\mathrm{km}$ and $18 \mathrm{~km}$ distances. Concentration of tar substances and PAHs was evaluated and compared with the data from 1987. The results show that PAH emissions from the plant decreased due to the aforementioned environmental investments, which in turn resulted in a significant drop of PAH concentration in soils in around the plant (1-3 km). Nevertheless, their level is still high (especially $1 \mathrm{~km}$ away from the refinery) when compared with uncontaminated sites.
\end{abstract}

Key words: petrochemical plant, soil contamination, PAHs.

\section{INTRODUCTION}

The Petrochemical Plant Orlen S.A. in Płock was constructed in the 1960s as one of the largest objects of this type in Europe. The facility was unfortunately located among agricultural areas, although the petrochemical industry is an identified source of numerous pollutants, among others - hydrocarbons. The research conducted at the beginning of the 1970s (Siewniak 1975) indicated the related risks. A much higher content of benzo/a/pyrene and phenanthrene was observed in soils in the refinery's close vicinity $(15100 \mu \mathrm{g} / \mathrm{kg} \mathrm{B} / \mathrm{a} / \mathrm{P}$ and 24100 $\mu \mathrm{g}$ phenanthrene per kg dry weight of soil) than in a $5 \mathrm{~km}$ distance (less than $2000 / \mu \mathrm{g} / \mathrm{kg} \mathrm{B} / \mathrm{a} / \mathrm{P}$ and $200-500 / \mu \mathrm{g} / \mathrm{kg}$ phenanthrene per kg d.w. of soil).

The political and economical changes of the 1990s resulted in a greater interest in environmental protection initiatives. The petrochemical plant implemented a number of investments aimed at lowering released pollutant loads. As a result, hydrocarbon emissions dropped by about $73 \%$. There is no information, however, whether these investments were successful in decreasing soil pollution with tar substances and polycyclic aromatic hydrocarbons (PAH) and raising the security level for agricultural production within the area.

Research conducted in the 1980s (Karaczun 1991, Indeka 1996, Indeka, Karaczun 2006) proves that the heavy 
metal and PAH content in soil and plants decreases along with the distance of sampling points from the facility. Indeka (1996) claims that PAH concentration in plants is statistically lower in samples collected 6-12 km away from the facility than in the samples collected closer to it. These results confirm earlier observations made by Siewniak (1975) that the highest hydrocarbon concentration occurred in the refinery's direct vicinity and stabilized at a significantly lower level 5 $\mathrm{km}$ away from it.

The aim of this research was to verify whether reduced hydrocarbon emissions (in 2006, compared with the 1980s) from the refinery had any impact on selected PAH concentration in soil of the agricultural areas surrounding the facility and whether the current PAH soil concentration allows for safe agricultural production in the area.

The research hypothesis assumes that the aforementioned environmental investments should reduce PAH soil concentration. If true, the current PAH soil concentration should be lower than in the 1980s and the decrease should be more significant in the samples collected closer to the emission source.

\section{METHODS}

The research was conducted within the agricultural area around the refinery in Płock. Soil samples were collected in the north-eastern direction from the facility (main wind direction), at five research points (area ca $10 \mathrm{ha}$ ) at $1 \mathrm{~km}, 3 \mathrm{~km}, 6$ $\mathrm{km}, 12 \mathrm{~km}$ and $18 \mathrm{~km}$ distances (as in the 1987 research). Arable soil layers from which the samples were collected had the following granulometric composition and $\mathrm{pH}$ in $\mathrm{H}_{2} \mathrm{O}$ : (1) - glp (light clay sandy), 6.0; (2) - glp, 6.4; (3) - glp, 5.9; (4) - pgmp (sand clayey solid sandy), $6.0 ;(5)$ - glp, 5.7. They were collected with Egner's sampling stick, at the turn of July and August. The samples (20-30) were taken in several places within each research point and mixed together to obtain an average sample. Soil was dried and sieved. The content of tar substances and polycyclic aromatic hydrocarbons was evaluated by means of the same methods as in 1987.

Hydrocarbons were extracted with benzene in a Soxhlet apparatus, then the extract was washed repeatedly in a separator with distilled water until it was clear. Subsequently, it was concentrated and once more purified on a silica gel column with a mixture of toluene and n-hexane $(2: 3)$. The material on the column was washed with a mixture (6 $\mathrm{ml})$ of n-hexane and toluene (20:1). The filtrate was concentrated and transferred to a column (NUCLEOSIL 100.C18/5 UM) of a liquid chromatograph (PPDRP Techma-Robot type 303; detector uv $254 \mathrm{M}$ ). Separation was carried out by means of a methanol-water-acetonitryl mobile phase $(40: 25: 35)$, speed of flow $10^{-2} \mathrm{~cm}^{3} / \mathrm{s}$. In order to calculate the volume of respective hydrocarbons, their peaks were defined and compared with the analytical curve. The following polycyclic aromatic hydrocarbons were covered by the analyses in 1987 and 2006: fluorantene (Flu), benzo(a)pyrene (BaP), benzo(e)pyrene (BeP), pyrene (Pir) and chrysene (Chr).

In order to assess soil PAH contamination and to compare the data with the standards (Podstawy oceny..., 
1995), the concentration of 16 PAHs was analysed in the chemical laboratory of the Institute of Soil Science and Plant Cultivation in Puławy. The analytical procedure applied has been already described (Maliszewska-Kordybach et al. 2008a; Maliszewska-Kordybach et al. 2008b).

\section{RESULTS AND DISCUSSION}

Table 1 presents the changes in tar substance content in soils from five research points in 2006, in comparison with 1987. Table 2 shows soil concentration levels for five PAHs in the same years, and Figure 1 illustrates the changes in PAH content in 2006, comparing to 1987.

The data presented above shows that tar substance and PAH concentration in soils around the Płock refinery was much lower in 2006 than in the 1980s. Average soil concentration for tar substances from all the research points was by around 21\% lower in 2006 than in 1987. For the PAHs analysed, their average soil concentration from all the research points was lower by $15.5 \%$ in 2006 than twenty years earlier.

The lower soil content of the substances analysed in the soils around the refinery is not sufficient, however, to prove that the decrease results from lower emissions from the plant. As already mentioned, PAH content in soils is very strongly related to the distance from the source of emission and the refinery's impact on PAH concentration was observed mainly in points closer to the plant (Siewniak 1975, Indeka 1991; Indeka 1996; Indeka and Karaczun 2006; Maliszewska-Kordybach and Smreczak 2003; Wong et al. 2004). 2006 research results show that the most significant

TABLE 1 . Tar substance content $(\mathrm{mg} / \mathrm{kg})$ in soils, at an increasing distance from the Płock refinery, in 1987 and 2006 (content in $1987=100 \%$ )

\begin{tabular}{|l|c|c|c|c|c|}
\hline \multirow{2}{*}{ Tar substancesin soils } & \multicolumn{5}{|c|}{ Research point } \\
\cline { 2 - 6 } & $1 \mathrm{~km}$ & $3 \mathrm{~km}$ & $6 \mathrm{~km}$ & $12 \mathrm{~km}$ & $18 \mathrm{~km}$ \\
\hline Content in 1987 & 576 & 370 & 278 & 254 & 266 \\
\hline Content in 2006 & 380 & 262 & 228 & 225 & 251 \\
\hline Change (\%) & 44.0 & 29.2 & 18.0 & 11.5 & 5.6 \\
\hline
\end{tabular}

TABLE 2. PAH content in soils $(\mu \mathrm{g} / \mathrm{kg})$, at an increasing distance from the Płock refinery, in 1987 and 2006

\begin{tabular}{|l|r|r|r|r|r|r|r|r|r|r|}
\hline \multirow{2}{*}{ PAH } & \multicolumn{10}{|c|}{ Content in research point } \\
\cline { 2 - 13 } & \multicolumn{2}{|c|}{$1 \mathrm{~km}$} & \multicolumn{2}{|c|}{$3 \mathrm{~km}$} & \multicolumn{2}{|c|}{$6 \mathrm{~km}$} & \multicolumn{2}{|c|}{$12 \mathrm{~km}$} & \multicolumn{2}{|c|}{$18 \mathrm{~km}$} \\
\hline & 1987 & 2006 & 1987 & 2006 & 1987 & 2006 & 1987 & 2006 & 1987 & 2006 \\
\hline $\mathrm{BaP}$ & 95 & 72 & 67 & 52 & 40 & 34 & 33 & 32 & 32 & 35 \\
\hline $\mathrm{BeP}$ & 278 & 204 & 162 & 128 & 82 & 79 & 75 & 76 & 88 & 84 \\
\hline $\mathrm{Chr}$ & 291 & 225 & 226 & 181 & 152 & 145 & 132 & 121 & 138 & 141 \\
\hline Pir & 680 & 545 & 506 & 381 & 253 & 232 & 240 & 222 & 254 & 247 \\
\hline Flu & 794 & 612 & 590 & 478 & 263 & 229 & 254 & 258 & 220 & 233 \\
\hline
\end{tabular}


decrease occurs in the points situated the closest to the plant: at the distances of 1 and $3 \mathrm{~km}$ (Tab. 2, Fig. 1). The decrease of PAH contamination in the points situated at $1 \mathrm{~km}$ and $3 \mathrm{~km}$ from the refinery may, therefore, be considered a result of the refinery's lower emissions. This is confirmed by the fact that the differences are much lower at $6 \mathrm{~km}$ and $12 \mathrm{~km}$ distances and no difference occurs (and even a slight increase was observed) at $18 \mathrm{~km}$ distance. $\mathrm{km}$ distances, is higher than the recommended concentration for agricultural soils in the Regulation.

According to a six-grade scale of soil PAH contamination, prepared by the Institute of Soil Science and Plant Cultivation (Podstawy oceny...,1995), the geometrical average of $16 \mathrm{PAH}$ content in arable soils that are not directly influenced by the atmospheric pollution immission, must not exceed $150 \mu \mathrm{g} / \mathrm{kg}$. Considering this criterion,

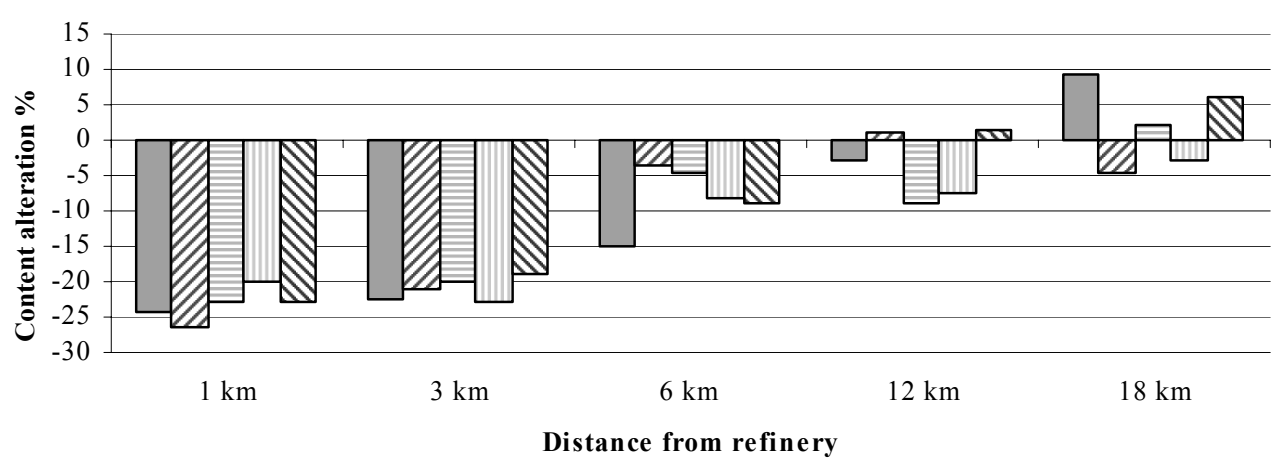

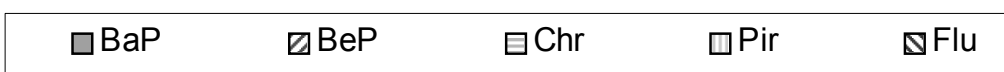

FIGURE 1. Change of PAH content (\%) in soils, at an increasing distance from the refinery - 2006 content, comparing to 1987

To evaluate the risk for agricultural production caused by soil PAH pollution in the Płock refinery impact zone, it is necessary to compare soil pollution within the area to recognized standards. The Regulation of the Minister of Environment of 2002 (Official Journal of Polish Laws No 165/1359) states that the sum of 9 PAHs must not exceed $1 \mathrm{mg} / \mathrm{kg}$ d.m. In accordance to this Regulation, the soil in question (Tab. 2 ) is not contaminated. Nevertheless, BaP soil content, especially at 1 and 3 all the analysed soils (Fig. 2) fall into the category of not contaminated, but with an increased (from 200 to $600 \mu \mathrm{g}$ PAH per kg d.w.) PAH content.

The research results indicate a significant impact of the Płock refinery's PAH emission up to a $3 \mathrm{~km}$ distance. Farther, the facility has a much lower influence on PAH soil contamination than other sources. The results are coherent with the previously obtained data (Indeka 1991; Indeka 1996). 


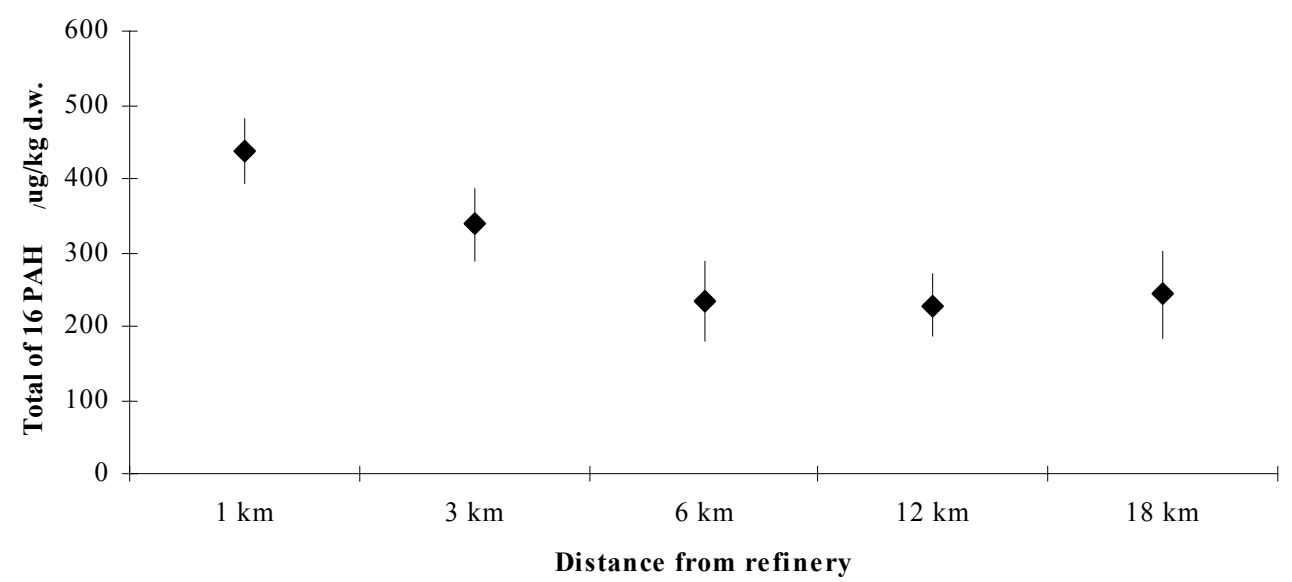

FIGURE 2. 16 PAH content in soils ( $\mu \mathrm{g} / \mathrm{kg}$ ), at an increasing distance from refinery, in 2007 (vertical line - standard deviation)

\section{CONCLUSIONS}

1. The results confirm the hypothesis that lower hydrocarbon emission from the Petrochemical Plant Orlen S.A. results in reduced pollution of agricultural soils with these substances in the plant's nearest vicinity.

2. The average content for the analysed PAHs from all the sampling points was lower by $15.5 \%$ in 2006 than before the environmental investments in the refinery.

3. A larger decrease in concentration of the analysed PAHs was observed in soils sampled from points more susceptible to emission from the plant, i.e. located $1 \mathrm{~km}$ and $3 \mathrm{~km}$ away from the refinery. The average soil content for the analysed PAHs in these points decreased by around $22 \%$ in $1987-2006$ and only by $4 \%$ for all the points located $6 \mathrm{~km}, 12 \mathrm{~km}$ and $18 \mathrm{~km}$ away from the plant.

4. 2006 research results show that although the refinery reduced the level of its hydrocarbon emission, it still remains an emission source for these substances to the environment. This is confirmed by the higher content of 16 PAHs in the soil sampled in the points the nearest to the plant $(1 \mathrm{~km}$ and $3 \mathrm{~km})$ than those at a larger distance $(6 \mathrm{~km}, 12 \mathrm{~km}, 18$ $\mathrm{km})$.

5. The current PAH soil content in the agricultural areas around the Petrochemical Plant Orlen S.A. does not pose a risk to the agricultural production in the area.

\section{REFERENCES}

INDEKA L. 1991: Zawartość benzo/a/pirenu w warzywach uprawianych w ogrodach działkowych w Płocku. W: "Wpływ zanieczyszczeń przemysłowych na gleby i uprawy". [Benzo/a/pyrene concentration in vegetables from private gardens in Płock. In: "Industrial pollution impact on soils and crops".] GEA 1; 131-136. Murzynowo. 
INDEKA L. 1996: Chemiczne skażenia wybranych roślin uprawianych $\mathrm{w}$ rejonie oddziaływania Mazowieckich Zakładów Refineryjnych i Petrochemicznych. [Chemical pollution of selected plants within the impact zone of the Mazovian Refinery and Petrochemical Plant] Rozprawy naukowe i monografie. Wyd. SGGW, Warszawa.

INDEKA L., KARACZUN Z.M. 2006: Pollution of soil land vegetables by polycyclic aromatic hydrocarbons within the zone of the Płock petrochemical plant emission. Ann. Warsaw Agricult. Univ. - SGGW, Horticult. And Landsc. Architekt., 27; 59-63.

KARACZUN Z.M. 1991: Wpływ przemysłu rafineryjno-pertochemicznego na poziom akumulacji metali ciężkich i siarki oraz aktywność biologiczną niektórych enzymów w użytkowanych rolniczo glebach okolic Płocka. [Impact of the refinery and petrochemical industry on the level of heavy metal and sulphur concentration and biological activity of selected enzymes within agriculturally utilized soils around Płock.] Praca doktorska. Wydział Ogrodniczy SGGW, Warszawa.

MALISZEWSKA-KORDYBACH B., KLIMKOWICZ-PAWLAS A., SMRECZAK B. 2008a: Soil reference materiale In ecotoxicity testing - application of the concept of EURO-SOIL to soil from Poland. Polish J. Env. Stud., 17; 257-266.

MALISZEWSKA-KORDYBACH B., SMRECZAK B. 2003: Habitat function of agricultural soils as affected by heavy metals and polycyclic aromatic hydrocarbons contamination. Environ. International, 28; 719-28.

MALISZEWSKA-KORDYBACH B., SMRECZAK B., KLIMOWICZ-PAWLAS A. TERELAK H. 2008b: Monitoring of the total content of polycyclic aromatic hydrocarbons (PAHs) in arable soils in Poland. Chemosphere, 73; 1284-1291.
Rozporządzenie Ministra Środowiska z dnia 9 września 2002 r. w sprawie standardów jakości gleby oraz standardów jakości ziemi. [Regulation of the Minister of Environment of 9 September 2002 on soil and earth quality standards] (DzU No 165/ 2002 poz. 1359).

PODSTAWY OCENY chemicznego zanieczyszczenia gleb: metale ciężkie, siarka i WWA. [Chemical soil pollution assessment: heavy metals, sulphur and PAHs] 1995. PIOŚ, IUNG. Biblioteka Monitoringu Środowiska, Warszawa.

SIEWNIAK M. 1975: Badania nad zanieczyszczeniem powietrza i gleby wokół zakładu petrochemicznego w Płocku. [Research into air and soil pollution around the Petrochemical Plant in Płock] Zeszyty Nauk. SGGW-AR, Warszawa.

WONG F., HARNER T., LIU Q.T., DIAMOND M.L. 2004: Using experimental and forest soils to investigate the uptake of polycyclic aromatic hydrocarbons (PAHs) along an urban-rural gradient. Environ. Pollut. $129 ; 387-398$.

Streszczenie: Ocena wptywu działań proekologicznych Zakladów Rafineryjnych w Płocku na zawartość wielopierścieniowych węlowodorów aromatycznych $w$ glebach na terenach sasiadujacych. Zakład PKN „Orlen” S.A. w Płocku (Petrochemia Płocka) wybudowano w latach 60. jako jeden $\mathrm{z}$ największych tego typu obiektów w Europie. Obiekt został zlokalizowany na terenach wykorzystywanych rolniczo, co powodowało, że w latach 60. i 70. gleby terenów rolniczych sąsiadujących $\mathrm{z}$ Petrochemią były bardzo zanieczyszczone węglowodorami aromatycznymi. W zakładzie dokonano inwestycji mających na celu zmniejszenie emisji zanieczyszczeń do środowiska. Emisja wielocyklicznych węglowodorów aromatycznych (WWA) spadła o ponad $70 \%$. Nie wiadomo jednak czy działania te spowodowały znaczący spadek zawartości tych substancji $\mathrm{w}$ sąsiadujących z zakładem glebach, a także czy obecny poziom zanieczyszczenia gleb jest bezpieczny dla produk- 
cji rolniczej. Odpowiedzi na te pytania stanowiły cel badań prowadzonych na rolniczych terenach zlokalizowanych w sąsiedztwie rafinerii.

Próbki gleb pobrano w pięciu punktach na kierunku północno-wschodnim w odległości 1 , 3, 6, 12 i $18 \mathrm{~km}$ od obiektu. Określono w nich zawartość substancji smolistych oraz WWA i porównano z danymi z 1987 roku. Spadek emisji WWA osiagnięty dzięki inwestycjom proekologicznym Petrochemii zaowocował znacznym obniżeniem ich zawartości w glebach na sąsiadujących terenach (1-3 km). Jednakże, zwłaszcza w odległości $1 \mathrm{~km}$ od rafinerii, poziom
WWA jest ciągle jeszcze wyższy w porównaniu $\mathrm{z}$ terenami uznawanymi za niezanieczyszczone.

MS. received March 2009

\section{Authors' address:}

Leonard Indeka, Zbigniew Karaczun, Grażyna Obidoska

Warsaw University of Life Sciences - SGGW

Department of Environmental Protection

02-787 Warszawa, ul. Nowoursynowska 166

Poland

e-mail: zbigniew_karaczun@sggw.pl 